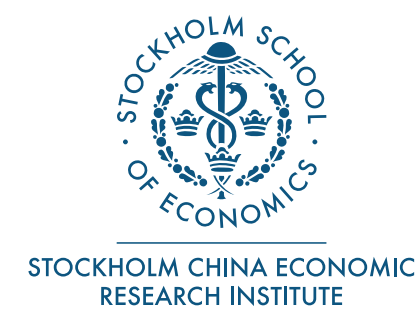

\title{
National and Regional Financial Openness in China
}

\author{
Xiuping Hua \\ Nottingham University Business School China \\ Anders C. Johansson \\ Stockholm School of Economics \\ Xun Wang \\ Stockholm School of Economics
}

\section{Stockholm School of Economics Asia Working Paper}

No. 38

August 2015 


\title{
National and Regional Financial Openness in China*
}

\author{
Xiuping Hua \\ Nottingham University Business School China \\ Anders C. Johansson \\ Stockholm School of Economics \\ Xun Wang ${ }^{\dagger}$ \\ Stockholm School of Economics
}

August 2015

\footnotetext{
* Financial support for Xiuping Hua and Xun Wang from British FCO’s China Prosperity SPF Programme (Project title: China's International Future in Finance, Trade and Business Innovation) is gratefully acknowledged.

${ }^{\dagger}$ Corresponding author, Stockholm School of Economics, P.O. Box 6501, SE-113 83 Stockholm, Sweden. Email: Xun.Wang@hhs.se.
} 


\title{
National and Regional Financial Openness in China
}

\begin{abstract}
While China's economy has been subject to a wide range of economic reforms since 1978 , its capital account is still restricted. The issue of capital account convertibility is widely debated both in China and by foreign observers. This study contributes to the understanding of China's capital account by constructing new indices for China's financial openness. First, we construct alternative indices, both of which suggest that China has experienced significant increases in its financial openness, albeit beginning at very low levels in the late 1970s. Then, we construct an index for financial openness at the provincial level from 2000. As expected, the eastern provinces exhibit much higher levels of financial openness than the provinces located in the central and western parts of the country. Taken together, these indices enable a clear overview of national and regional financial openness across time and are well suited for future studies on determinants and effects of financial openness in China.
\end{abstract}

JEL Codes: F21; F32; F42; G20

Keywords: Financial openness; Capital account; Capital controls; Convertibility; China 


\section{1! Introduction}

As financial integration is increasing globally, financial markets in countries that have been closed off are opening up to the outside world. This is especially true for many emerging economies, where capital account liberalization constitutes one important component in the process of financial liberalization. In larger countries, the continued development of domestic financial markets and deregulation has also resulted in increased flows across regions. Both of these features especially apply to China, a country with a long tradition of repressive financial policies that are slowly being replaced by liberalized capital markets. This paper studies the dynamics of international and domestic financial openness. To do this, we construct indices for both national and provincial openness in China.

External financial liberalization or financial openness can be defined as the removal of barriers to the free flow of capital between countries (Eichengreen et al., 1998). At least in theory, economists have traditionally viewed financial openness as a means to promote economic development and maximize national wealth (Makin, 1994). This has two primary reasons. First, access to foreign capital can promote domestic growth by allowing a country to invest more than its savings, or import more than it exports. Second, it can increase the efficiency of investment by allowing funds to reach projects that yield the highest rate of expected return on an international scale.

However, experiences in many developing countries have shown that these benefits do not 
come automatically. Financial openness has frequently coincided with an unsustainable increase in foreign debt and domestic consumption, a rapid increase of unproductive investment and sharp fluctuations in exchange rates, equity indices and asset prices (Diaz-Alejandro, 1985; McKinnon and Pill, 1996). Contributions to the literature on financial crises have argued that the likelihood of a banking crisis and/or currency crisis increases as a result of financial liberalization (e.g. Caprio and Klingebiel, 1996; Demirguc-Kunt and Detragiache, 1998, 2001; Kaminsky and Reinhart, 1999; Gruben et al., 2003; Daniel and Jones, 2007). A typical and often mentioned example of this relationship is the Asian financial crisis in 1997, which erupted after a period of financial liberalization in many of the countries throughout the region that were hit the hardest (Chang and Velasco, 1998; Furman and Stiglitz, 1998; Corsetti et al., 1999). ${ }^{3}$ Later studies have tried to compare the final outcome of these potential positive and negative effects. For example, in a study that decomposes the effects of financial liberalization on economic growth and the incidence of financial crises, Ranciere et al. (2006) find that the direct effect on economic growth greatly outweighs the indirect effect of a larger likelihood of financial crisis.

In an early study, McKibbin and Tang (2000) analyze the consequences of China's rapid external financial liberalization. They show that when financial openness coincided with invest

\footnotetext{
${ }^{3}$ It has been has argued that financial liberalization played a decisive role in a number of other prolific financial crises, including Chile in 1982, Sweden and Finland in 1991-1992, and Mexico in 1994 (e.g. Diaz-Alejandro, 1985; Velasco, 1987; Dornbusch et al., 1995; Calvo and Mendoza, 1996; Sachs et al., 1996; Jonung, 2008).
} 
confidence in the Chinese economy, large capital inflows surged and investment and real GDP were left permanently higher. However, even in this optimistic scenario, the real and nominal exchange rate appreciated close to 50 percent, crowding out net exports and leading to deterioration in the current account position of nearly 4 percent. In the alternative scenario, where financial openness was followed by a loss of confidence in China's financial reforms, the predicted capital outflow was severe, causing consumption and investment to be below the level that would have been achieved if no financial openness had been undertaken. Taking into account these potential risks, the process of financial openness in China as a means to promote economic development should be evaluated cautiously. In line with this reasoning, the Chinese government has adopted a prudential and gradual process of financial openness.

To better understand the gradual reform process and how it has affected different parts of the countries, and to enable further analysis of the process of financial opening in China, we construct financial openness indices at both the national and provincial levels. While leaving a more detailed analysis of the effects of financial opening on the economy to future studies, this paper focuses on the degree of financial openness from 1977 and onward as well as its regional variation in China. At the national level, we find that financial openness, while still relatively modest, has been increasing steadily since the beginning of the economic reforms in the end of the 1970s. As expected, we find a considerable variation across provinces, with a much higher degree of financial openness in the eastern provinces, which decreases as we move towards the 
western part of the country.

The rest of this paper is organized as follows. Section 2 reviews the relevant literature; Section 3 presents the evolution of China's capital account liberalization; Section 4 constructs the de jure and de facto financial openness indices at the national level, while Section 5 constructs the financial openness index at the provincial level. Finally, Section 6 concludes the paper.

\section{2! Literature Review}

As capital account liberalization and financial liberalization in general have continued around the world since the end of the Bretton Woods System in the 1970s, it has drawn the attention of scholars who have amassed a large body of literature. This literature can best be divided into three strands (Huang et al., 2011): the measurement of capital controls; the effectiveness of capital controls; and the relationship between capital controls and its consequences on different aspects of national economic performance. Here, we focus on the first of these, namely that of how to measure capital account controls. ${ }^{4}$

There are two common ways to measure capital controls: the de jure and the de facto

\footnotetext{
${ }^{4}$ For more on the effectiveness of capital controls, see, e.g., Càrdenas and Berrera (1997), Cardoso and Goldfajn (1998), Montiel and Reinhart (1999), De Gregorio et al. (2000), and Binici et al. (2010). For detailed discussions and analyzes on the capital account and various forms of national economic performance, see, among others, Quinn (1997), Eichengreen (2001), Stiglitz (2003), Edison et al. (2004), Bekaert et al. (2005), Desai et al. (2006), Gourinchas and Jeanne (2006), Kose et al. (2009), and Quinn and Toyoda (2008).
} 
approaches. The way de jure-based indices are constructed means that they provide information about the general policy or legislation a country has implemented for its capital account. Typically, such indices are constructed using data from the IMF's Annual Report on Exchange Arrangements and Exchange Restrictions (AREAER) and/or the OECD's Code of Liberalization of Capital Movement. The most straightforward approach is to use a binary dummy for each category. Using this approach, 1 would represent full control and 0 no control, or the proportion of categories without restriction (e.g. Epstein and Schor 1992; Klein and Olivei, 2008). Some studies that apply de jure-based indices have attempted to distinguish between different degrees of controls (e.g. Quinn, 1997; Montiel and Reinhardt 1999). For example, 0.25 could imply light control, while 0.75 would indicate a high level of control.

One typical criticism towards the de jure approach is that it does not take into consideration the fact that formal restrictions on capital movements are often circumvented (Edwards, 2005). This means that while such indices give us an understanding of the official policy for capital movements, they do not provide a full picture of the actual degree of capital account openness. As a result, some scholars prefer the so-called de facto approach, which focuses on the actual flows rather than official policy.

De facto indices can be classified into three groups. First, quantity indices measure the ratio of gross cross-border capital flows to GDP (e.g. Lane and Milesi-Ferretti 2001, 2007). The fact that this type of indices focuses on the actual flows means that it may reflect a range of factors in 
addition to capital controls. For example, capital flows are likely to be closely associated with expectations of future returns on investments and general perceptions of risk within different countries. Second, price indices are based on the law of one price, which is based on the assumption of an open capital account. A direct result of the law of one price is that we can gauge the level of capital controls by analyzing the prices of equivalent assets across countries

(e.g. Dooley et al. 1997; Yeyati et al. 2009). Price deviations can thus be characterized as de facto capital controls. Third, there are different forms of hybrid measures. For example, Feldstein and Horioka (1980) in their famous study on domestic savings and investment find it puzzling that the two are so highly correlated, as one would expect rational investors to invest in countries that offer the highest return on their capital. Using this framework, a high level of correlation between domestic saving and investment thus suggests a low level of capital mobility.

In this study, we tentatively construct financial openness indices at both in national level and provincial level. We first construct a capital account control index, following the de jure approach, which focuses on legislation than on actual flows. Later, we also estimate cross-border capital flows, following the de facto approach. Both indicators show that actual restrictions on capital flows have been weakened, most clearly during the first decade of the 21 st century.

\section{3! An Overview of China's Capital Account Liberalization}

When China began its economic reform in the late 1970s, its capital account was tightly 
controlled. In fact, there was almost no cross-border capital flow. The current account was basically balanced, as amounts of exports were determined by requirement of foreign exchanges for imports. During the reform period, the government carefully pushed forward liberalization of capital controls, following the general strategy of 'long-term first, short-term later; inflow first, outflow later; equity investment first, portfolio investment later'. In some areas, such as inward foreign direct investment (FDI), capital flows are quite free.

Currently, capital account controls exist in three main areas. First, in opening the securities markets to foreign investors, the Chinese government pursued a strategy of "segmenting the markets with different investors". Foreign investors are only allowed to buy foreign currency denominated shares and debt instruments, such as the B shares, $\mathrm{H}$ shares and red chips stocks. However, they are not allowed to buy renminbi-denominated A shares, bonds or other money market instruments, unless they have Qualified Foreign Institutional Investor (QFII) quota. Meanwhile, Chinese residents are largely prohibited from buying, selling or issuing capital or money market instruments in the overseas markets outside the Qualified Domestic Institutional Investor (QDII) scheme.

Second, while foreign-funded enterprises are free from any restrictions on raising short- or long-term debts in the overseas market, other domestic entities need to obtain necessary qualifications as the main borrowers and to have the proposed borrowing quotas and terms certified or approved by the authorities. In addition, domestic financial institutions can only issue 
external loans in line with certain provisions set in the rules on foreign exchange liability/asset ratio management. Domestic non-financial enterprises are strictly prohibited from extending any external loans.

And, finally, for foreign investors, no restrictions, other than the industry policy, are imposed on their direct investment in China. However, outward direct investment (ODI) by domestic entities needs to be approved by the State Administration of Foreign Exchange (SAFE), the Ministry of Finance (MOF) and the National Development and Reform Commission (NDRC).

Government restrictions on the capital account primarily involve the following two types: controls imposed on cross-border capital transactions and controls imposed on certain phases of foreign exchange transactions related to cross-border capital transactions by the SAFE, including restrictions on cross-border fund remittance and repatriation and $\mathrm{RMB} /$ foreign currency exchange related to capital account transactions.

\section{4! Constructing a National Index of Capital Account Openness}

There are roughly two ways of measuring the capital account openness. One way is to look into the extensity and intensity of regulatory controls on cross-border capital transactions. Such a de jure approach usually uses information from the IMF's Annual Report on Exchange Arrangements and Exchange Restrictions (AREAER) (Quinn 1997; Montiel and Reinhardt 1999; 
Chinn and Ito, 2006, 2008; Quinn and Toyoda, 2008). The other approach is to construct a de facto measure of financial openness (Lane and Milesi-Ferretti 2003, 2007). To enhance the reliability of our estimation, we construct both de jure and de facto index.

\section{1! De Jure Measure of Capital Account Openness}

In order to quantify the capital account controls, especially changes over time, we construct a quantitative index, CACI. Following Jin (2004), Xiao and Kimball (2005), we estimate degrees of restriction for all 11 categories of capital account transactions ${ }^{5}$, applying classifications by OECD and China's State Administration of Foreign Exchange (SAFE). We first set each category to 3 for the years before 1978, meaning strict control. Likewise an index of 2 refers to strong control, 1 slight control, and 0 liberalized. Finally, CACI is normalized to the $0-1$ range.

To trace the historical evolution, we collected 73 out of 144 laws and regulations issued by SAFE between 1977 and 2010. Each observation was deemed as an event. We update the index in response to every event so as to construct a monthly index. The responsive grading criterion is as follows: significant changes in laws and regulations result in 1 point; insignificant changes result in 0.5 point. We define the significant changes as changes in beneficiaries. Insignificant changes are defined as quota limit adjustment, duration adjustment and provisional acts or pilot

\footnotetext{
5 These 11 categories are as follows: capital market securities; money market instruments; collective investment securities; derivatives and other instruments; commercial and financial credits; guarantees, sureties, and financial backup facilities; outward direct investment; foreign (inward) direct investment; liquidation of direct investment; real estate transactions; and personal capital movement.
} 
projects being normalized. According to the definition of SAFE, the discrepancy between 'slightly controlled' and 'heavily controlled' is the range of transaction subjects. If an event changes the range of beneficiaries, such as developing from nothing or expanding from residents to all the transaction subjects, it should be deemed as a significant change.

[Figure 1 Here]

The final CACI confirms China's steady trend of capital account liberalization during the reform period (see Figure1). It started with 1 in 1977, suggesting almost complete controls. However, CACI came down quickly to around 0.9 when the government loosened controls on commercial and financial credits, foreign direct investment and liquidation of direct investment. Exchange rate policy reform in 1994, realization of the current account convertibility in late 1996 and the WTO accession in late 2001 all accelerated the decline of CACI. In 2010, it stood at slightly below 0.6 .

Two exogenous shocks i.e., the Asia Financial Crisis in 1997 and the Global Financial Crisis in 2007 should be noted as they have influenced the financial openness in China. Even though the crisis in 1997, which involved a number of countries in East and Southeast Asia, most likely was not the only reason for the halt in the liberalization process towards the end of the 1990s, it did play an important role. Leading up the global financial crisis a decade later, further steps 
towards an open capital account were minuscule. Similar to the Asian financial crisis, the global financial crisis weakened the arguments in favor of a further opening of the capital account as the country to some extent was shielded against external financial shocks due to its capital controls. As shown clearly in Figure 1, the de jure index increased a little bit during 1997 and 2007, respectively.

\section{2! De Facto Measure of Capital Account Openness}

It should be noted that de jure measures fail to fully capture the complexity of real-world capital controls. Therefore, following Lane and Melesi-Ferretti (2003), we construct a volume-based measure of financial openness.

$$
\text { FOPEN1 } 1_{t}=\frac{\mathrm{FA}_{\mathrm{t}}+\mathrm{FL}_{\mathrm{t}}}{\mathrm{GDP}_{\mathrm{t}}},
$$

where FA (FL) denotes the stock of external assets (liabilities). Figure 2 plots this ratio over the period 1981-2010. Over this period, the ratio has increased by a factor of 8 , from $13.3 \%$ in 1981 to $109.7 \%$. During the first two decades of the reform period, the 1980s and 1990s, the increase in financial openness was relatively stable (FOPEN1 reached 70\%), but accelerated after 2000 (FOPEN1 passed $110 \%$ in 2004).

One striking fact in China's external assets is the rapid accumulation of foreign exchange 
reserves. Foreign exchange reserves (minus gold) increased from 5 billion USD in 1981 to 158 billion in 2000 and reached over 3 trillion USD at the end of 2011, accounting of $68.6 \%$ of the total external assets. There is little doubt that large foreign exchange reserves play a key role in the measure of FOPEN1. However, large foreign exchange reserves do not necessarily mean a more liberalized capital account. Taking this effect into account and following Lane and Melesi-Ferretti (2007), we report a second measure of capital account openness in China based on equity and FDI stocks:

$$
\mathrm{FOPEN} 2_{2}=\frac{\mathrm{EQA}_{\mathrm{t}}+\mathrm{ODI}_{\mathrm{t}}+\mathrm{EQL}_{\mathrm{t}}+\mathrm{FDI}_{\mathrm{t}}}{\mathrm{GDP}_{\mathrm{t}}},
$$

where EQA (EQL) denotes the stock of equity assets (liabilities) and ODI (FDI) denotes the stock of outward direct investment (foreign direct investment). Figure 2 (the dotted line) shows the evolution of FOPEN2. Compared with FOPEN1, increase in FOPEN2 is fairly gradual. The ratio has increased from $0.5 \%$ in 1981 to $36.4 \%$ in 2010. As shown in Figure 2, it is also worth noting that the financial crises that occurred in 1997 and 2008 significantly affected the capital flows in and out of China. Due to the crisis, the relative size of capital flow decreased. Since China imposes relatively restrictive regulation on capital outflows, the relative size of capital outflows decreased as well. The reductions of capital flows in both directions thus resulted in downward adjustments in FOPEN1 and FOPEN2. 
[Figure 2 Here]

\section{5! Constructing a Provincial Financial Openness Index}

To construct a de jure index of capital account control at the provincial level, we need province-specific policies on capital flows in order to capture relative restrictions between provinces from the policy perspective. However, restrictive policies for the capital account set up by SAFE are at the national level. Therefore, we cannot obtain different restrictive policies at the provincial level. Although there are few fluctuations in regions by de jure measurements, it does not necessarily mean that different provinces exhibit similar levels of cross-border capital movements. Coastal areas are more developed and attract more foreign direct investment. At the same time, enterprises located there often have better opportunities to invest abroad. In contrast, the central and western regions are less developed and less FDI flows in and out. It is reasonable to believe that the eastern region has higher level of capital mobility than the central and western regions. Therefore, a de facto measure of financial openness is a suitable alternative to capture different levels of capital mobility across provinces.

\section{1! FDI Inflows across Provinces}

FDI has played an important role for China's rapid economic growth since the beginning of 
the economic reforms. Since the early 1980s, inward FDI flows have increased steadily but unbalanced across regions. Due to government policies and geographic advantages, coastal areas in the east have attracted most of the FDI inflows while much less FDI investments have reached the central and western areas.

Figure 3 depicts the ratio of FDI to GDP across China's provinces from 2001 to 2010 . We select six representative provinces among 31 provinces to illustrate FDI inflows in different regions. Beijing and Shanghai thus represent the eastern region, Anhui and Hunan the central region, and Gansu and Yunnan the western region. As expected, Beijing and Shanghai are at the top, Anhui and Hunan are in the middle and Gansu and Yunnan are at the bottom in terms of FDI inflows during this period.

[Figure 3 Here]

\section{2! OFDI Outflows across Provinces}

Developing countries are becoming an increasingly important source of outward direct investment (ODI) around the world. The share that developing countries account for in terms of world outward FDI stock (flow) rose from $12.5 \%(3.1 \%)$ in 1981 to $17.5 \%(22.6 \%)$ in 2000 . ODI from developing Asia accounted for 73\% of the total ODI from the developing world in 2011 (UNCTAD). 
A majority of Asia's ODI originates from the four newly industrialized economies (NIEs)-Singapore, Hong Kong, South Korea and Taiwan. However, China is becoming an increasingly important player when it comes to global ODI. Coinciding with the drastic expansion of the current account surplus, China's ODI flow increased rapidly, from less than 1 billion in 2000 to more than 65 billion in 2011. China's share in developing Asia rose from 2.7\% to $55.5 \%$ during the same period. China is now not only the largest investor among the developing countries, but also among the largest investors in the world.

Figure 4 depicts the ratio of ODI to GDP across provinces from 2003 to 2010. A positive trend is evident in the ratio of all the selected provinces, indicating that China's outward foreign direct investment is steadily increasing. The ratios of ODI to GDP in Beijing and Shanghai remain at the top. However, unlike the FDI ratios, the ODI ratios in Gansu and Yunnan are slightly higher than those of Anhui and Hunan, a finding that is likely due to the volume of cross-border exchange in that region.

[Figure 4 Here]

\section{3! Provincial Financial Openness}

Due to capital account controls in China, portfolio assets and liabilities are mainly governed by QDII (QFII: inward, Foreign currency), QFII (QFII: inward, Foreign currency), Renminbi 
Qualified Foreign Institutional Investor (RQFII: inward, RMB) schemes, respectively. Domestic investors can invest in foreign security markets through QDII. And foreign investors have the opportunity to invest in China's security markets through QFII and, very recently, RQFII. However, it is difficult to monitor which province equity assets come from and to which province equity liabilities flow. For example, equity liabilities in QFII will be invested in the two stock exchange markets in Shanghai and Shenzhen but we cannot monitor which company the funds are invested in. Hence, it is impossible to monitor into which region the funds eventually flow.

Taking this into account, we use the ratio of direct investment to GDP as a proxy of regional financial openness. Basically, the larger the direct investments are in a specific province, the higher the financial openness is for that province. We thus construct provincial the financial openness index the following way:

$$
\mathrm{FOPEN}_{\mathrm{it}}=\frac{\mathrm{FDI}_{\mathrm{it}}+\mathrm{ODI}_{\mathrm{it}}}{\mathrm{GDP}_{\mathrm{it}}},
$$

where $\mathrm{FDI}_{\mathrm{it}}\left(\mathrm{ODI}_{\mathrm{it}}\right)$ denotes the stock of foreign direct investment (outward direct investment) in province $i$ at year $t$. 
Due to the data availability, we construct the provincial index for the period 2001 to 2010 . Table 1 presents the average financial openness index across provinces. Tianjin ranks the highest with a financial openness index of 0.089 , followed by Fujian, Shanghai, Jiangsu, Liaoning and Guangdong, respectively. The last five provinces when comparing the ratio of FDI and ODI to GDP are Yunnan, Xinjiang, Gansu, Guizhou and Tibet, respectively. These findings are in line with our predictions. The most financially open provinces are located in China's eastern region. Central provinces are moderately open, while provinces in the western part of the country exhibit the lowest levels of financial openness. These findings are as expected as the eastern region attracts more FDI and invests more abroad, something that in turn likely results in more portfolio investments as well. Overall, these features of the provinces in the eastern part of the country can be attributed to the general level of economic development, the geographic location, and the fact that economic reforms in the country were gradual in nature and the coastal regions played a key role in that gradual process. Correspondingly, the central and western regions are less developed, are not as close to international trading routes, and were not included in the economic reforms until much later. Hence, capital movements in and out of provinces in the central and western regions are lower than those in the eastern part of the country.

We also depict financial openness indexes for several representative provinces (see Figure 5). As expected, the eastern region (represented by Beijing and Shanghai) is on top, the central 
region (represented by Anhui and Hunan) is in the middle, and the western region (represented by Gansu and Yunnan) is at the bottom. These findings again suggest that the eastern region exhibits the highest level of financial openness, whereas the western region is characterized by a much lower level of financial openness.

[Figure 5 Here]

\section{6! Conclusion}

The question of whether or not to open up the capital account in China has been widely debated. Proponents for financial openness argue that the capital account liberalization and global financial integration of China has the potential to be a driver of economic growth and financial stability, not only in China but also globally. Those who argue against it most often refer to the increased risk for financial crisis as a reason not to liberalize, a risk that is potentially more significant if a country is still in a relatively early phase of development. The debate on pros and cons of capital account liberalization is perhaps particularly relevant for China, where the government has been discussing whether or not to open up the capital account since the 1980s, but has yet to implement such a reform. As arguments for a comprehensive reform of the

financial system, including the capital account, are increasingly being heard in China, a thorough 
understanding of developments in terms of the capital account during the period of economic transition is crucial. To facilitate such an analysis, this study develops new financial openness indices at the national level. In addition, a better understanding of provincial financial openness will help future studies that analyze potential determinants and effects of regional financial openness in China. This study therefore also develops a new index for financial openness at the provincial level.

Our preliminary findings show that China has experienced a gradual opening up of its capital account. This change originates from a level of complete control in the late 1970s. Our findings also suggest that capital controls are far from complete, an intuitive finding given the fact that, so far, only certain parts of the capital account have been opened up to the rest of the world. At the regional level, we find that provinces located in the eastern part of the country exhibit relatively higher levels of financial openness, with lower levels of openness in the central region. The lowest levels of financial openness are found in the provinces located in the western part of the country. These findings are also as expected, as economic development, geographic location, and the overall reform strategy by the central government influence the relative level of financial openness across the country.

While our findings are tentative, they provide for a clear picture of the evolution of financial openness at the national and provincial level in China. A natural next step is to use these indices to analyze different aspects of financial openness in the country. Potential future studies for 
which these indices are suitable include the analysis of financial openness and growth at the national and regional level, economic policy and regional financial openness, and the relationship between financial openness and financial development across China. 


\section{References}

Bekaert, G., Harvey, C.R., Lundblad, C., 2005. Does Financial Liberalization Spur Growth? Journal of Financial Economics 77, 3-55.

Binici, M., Hutchison, M., Schindler, M., 2010. Controlling Capital? Legal Restrictions and the Asset Composition of International Financial Flows. Journal of International Money and Finance 29, 666-684.

Calvo, G.A., Mendoza, E.G., 1996. Mexico's Balance-of-Payments Crisis: A Chronicle of a Death Foretold. Journal of International Economics 41, 235-264.

Caprio, G., Klingebiel, D., 1996. Bank Insolvency: Cross-Country Experiences. World Bank Working Paper No. 1620.

Càrdenas, M., Barrera, F., 1997. On the Effectiveness of Capital Controls: The Experience of Colombia during the 1990s. Journal of Development Economics 54, 27-57.

Cardoso, E., Goldfajn, I., 1998. Capital Flows to Brazil: The Endogeneity of Capital Controls. IMF Staff Papers 45, 161-202.

Chang, R., Velasco, A., 1998. Financial Crises in Emerging Markets: A Canonical Model. NBER Working Paper No. 6606.

Chinn, M.D., Ito, H., 2006. What Matters for Financial Development? Capital Controls, Institutions, and Interactions. Journal of Development Economics 81, 163-192.

Chinn, M.D., Ito, H., 2008. Global Current Account Imbalances: American Fiscal Policy versus East Asian Savings. Review of International Economics 16, 479-498.

Corsetti, G., Pesenti, P., Roubini, N., 1999. What Caused the Asian Currency and Financial Crisis? Japan and the World Economy 11, 305-373.

Daniel, B.C., Jones, J.B., 2007. Financial Liberalization and Banking Crises in Emerging Economies. Journal of International Economics 72, 202-221.

De Gregorio, J., Edwards, S., Valdés, R., 2000. Controls on Capital Inflows: Do They Work? Journal of Development Economics 3, 59-83.

Demirguc-Kunt, A., Detragiache, E., 1998. Financial Liberalization and Financial Fragility. IMF Working Paper No. 98/83.

Demirguc-Kunt, A., Detragiache, E., 2001. Financial Liberalization and Financial Fragility. In Caprio, G., Honohan, P., Stiglitz, J. (eds). Financial Liberalization. How Far, How Fast? 
Cambridge University Press: Cambridge.

Desai, M.A., Foley, C.F., Hines, J.R., 2006. Capital Controls, Liberalizations, and Foreign Direct Investment. Review of Financial Studies 19, 1433-1464.

Diaz-Alejandro, C., 1985. Good-Bye Financial Repression, Hello Financial Crash. Journal of Development Economics 19, 1-24.

Dooley, M.P., Mathieson, D.J., Rojas-Suarez, L., 1997. Capital Mobility and Exchange Market Intervention in Developing Countries. NBER Working Paper No. 6247.

Dornbusch, R., Goldfajn, I., Valdés, R.O., Edwards, S., Bruno, M., 1995. Currency Crises and Collapses. Brookings Papers in Economic Activity 2, 219-293.

Edison, H.J., Klein, M.W., Ricci, L., Sløk, T., 2004. Capital Account Liberalization and Economic Performance: Survey and Synthesis. International Monetary Staff Paper No. $02 / 120$.

Edwards, S. 2005. Capital Controls, Sudden Stops, and Current Account Reversals. NBER Working Paper No. 11170.

Eichengreen, B., Mussa, M., Dell'Ariccia, G., Detragiache, E., Milesi-Ferretti, G. and Tweedie, A. 1998. Capital Account Liberalization: Theoretical and Practical Aspects. IMF Occasional Paper No. 172.

Eichengreen, B.J., 2001. Capital Account Liberalization: What Do the Cross-Country Studies Tell Us? World Bank Economic Review 15, 341-366.

Epstein, G.A., Schor, J.B., 1992. Structural Determinants and Economic Effects of Capital Controls. In Banuri, T., Schor, J.B. (eds). Financial Openness and National Autonomy. Oxford: Clarendon.

Feldstein, M., Horioka, C., 1980. Domestic Saving and International Capital Flows. Economic Journal 90, 314-329.

Furman, J., Stiglitz, J., 1998. Economic Crises: Evidence and insights from East Asia. Brookings Papers on Economic Activity 29, 1-136.

Gourinchas, P.O., Jeanne, O., 2006. The Elusive Gains from International Financial Integration. Review of Economics Studies 73, 715-741.

Gruben, W., Koo, J., Moore, R., 2003. Financial Liberalization, Market Discipline and Bank Risk. CLAE Working Paper No. 0303.

Huang, Y., Wang, X., 2011. Does Financial Repression Inhibit or Facilitate Economic Growth? A 
Case Study of Chinese Reform Experience. Oxford Bulletin of Economics and Statistics 73, 833-855.

Huang, Y., Wang, X., Wang, B., Lin, N., 2013. Financial Reform in China: Progress and Challenges. In Park. Y. C., Patrick, H. (eds). How Finance Is Shaping the Economies of China, Japan and Korea. New York: Columbia University Press.

Jin, L., 2004. Intensity of Capital Controls in China. Journal of Financial Research 12, 9-23.

Jonung, L., 2008. Lessons from Financial Liberalization in Scandinavia. Comparative Economic Studies 50, 564-598.

Johansson, A.C., 2012. Financial Repression and China's Economic Imbalances. In McKay, H., Song, L. (eds), Rebalancing and Sustaining Growth in China, Canberra: ANU E Press.

Kaminsky, G., Reinhart, C., 1999. The Twin Crises: The Causes of Banking and Balance-of-payments Problems. American Economic Review 89, 473-500.

Klein, M.W., Olivei, G.P., 2008. Capital Account Liberalization, Financial Depth, and Economic Growth. Journal of International Money and Finance 27, 861-875.

Kose, M.A., Prasad, E., Rogoff, K., Wei, S.-J., 2009. Financial Globalization: A Reappraisal. IMF Staff Papers 56, 8-62.

Lane, P.R., Milesi-Ferretti, G.M., 2001. The External Wealth of Nations: Measures of Foreign Assets and Liabilities for Industrial and Developing Countries. Journal of International Economics 55, 263-294.

Lane, P.R., Milesi-Ferretti, G.M., 2003. International Financial Integration. IMF Staff Papers 50, 82-113.

Lane, P.R., Milesi-Ferretti, G.M., 2007. The External Wealth of Nations Mark II: Revised and Extended Estimates of Foreign Assets and Liabilities, 1970-2004. Journal of International Economics 73, 223-250.

Makin, A. J., 1994. International Capital Mobility and External Account Determinations. New York: St Martin's Press.

McKibbin, W.,J., Tang, K.K., 2000. Trade and Financial Reform in China: Impacts on the WEorld Econom. The World Economy 23, 979-1003.

Mckinnon, R. I. and Pill, H., 1996. Credible Liberalizations and International Capital Flows: The Overborrowing Syndrome." In Ito T. and Krueger A. O. (eds.). Financial Deregulation and Integration in East Asia, pp. 7-42. Chicago, IL: Chicago University 
Montiel, P., Reinhart, C.M., 1999. Do Capital Controls and Macroeconomic Policies Influence the Volume and Composition of Capital Flows? Evidence from the 1990s. Journal of International Money and Finance 18, 619-635,

Quinn, D., 1997. The Correlates of Change in International Finance Regulation. American Political Science Review 91, 531-551.

Quinn, D.P., Maria Toyoda, A.M., 2008. Does Capital Account Liberalization Lead to Economic Growth? Review of Financial Studies 21, 1403-1449.

Ranciere, R., Tornell, A., Westermann, F., 2006. Decomposing the Effects of Financial Liberalization: Crises vs. Growth. Journal of Banking and Finance 30, 3331-3348.

Sachs, J.D., Tornell, A., Velasco, A., Calvo, G.A., Cooper, R.N., 1996. Financial Crises in Emerging Markets: The Lessons from 1995. Brookings Papers on Economic Activity 1, 147-215.

Stiglitz, J. E., 2003. Globalization and Its Discontents. New York: W.W. Norton.

Velasco, A., 1987. Financial Crises and Balance of Payment Crises: A Simple Model of the Southern Cone Experience. Journal of Development Economics 27, 263-283.

Xiao, F., Kimball, D., 2005. Effectiveness and Effects of China's Capital Controls. China and World Economy 13, 58-69.

Yeyati, E.L., Schmukler, S.L., Van Horen, N., 2009. International Financial Integration through the Law of One Price: The Role of Liquidity and Capital Controls. Journal of Financial Intermediation 18, 432-463. 
Table 1 Average Financial Openness Index 2001-2010

\begin{tabular}{lccccc}
\hline \hline Province & Ranking & FOPEN & Province & Ranking & FOPEN \\
\hline Tianjin & 1 & 0.089 & Chongqing & 17 & 0.025 \\
Fujian & 2 & 0.075 & Hubei & 18 & 0.025 \\
Shanghai & 3 & 0.072 & Anhui & 19 & 0.019 \\
Jianngsu & 4 & 0.068 & Hebei & 20 & 0.016 \\
Liaoning & 5 & 0.064 & Sichuan & 21 & 0.015 \\
Guangdong & 6 & 0.064 & Shanxi & 22 & 0.015 \\
Hainan & 7 & 0.063 & Ningxia & 23 & 0.014 \\
Beijing & 8 & 0.049 & Henan & 24 & 0.012 \\
Jiejiang & 9 & 0.042 & Shaxi & 25 & 0.011 \\
Jiangxi & 10 & 0.040 & Guangxi & 26 & 0.011 \\
Shangdong & 11 & 0.036 & Yunnan & 27 & 0.010 \\
Jilin & 12 & 0.029 & Xinjiang & 28 & 0.009 \\
Heilongjiang & 13 & 0.029 & Gansu & 29 & 0.008 \\
Qinghai & 14 & 0.028 & Guizhou & 30 & 0.006 \\
Hunan & 15 & 0.026 & Tibet & 31 & 0.005 \\
Neimenggu & 16 & 0.026 & & & \\
\hline
\end{tabular}

Source: NBS, Statistical Bulletin of China's Outward Foreign Direct Investment, and author's calculations. 
Figure 1 Capital Account Control Index for China, 1977-2010(1977=1.0)

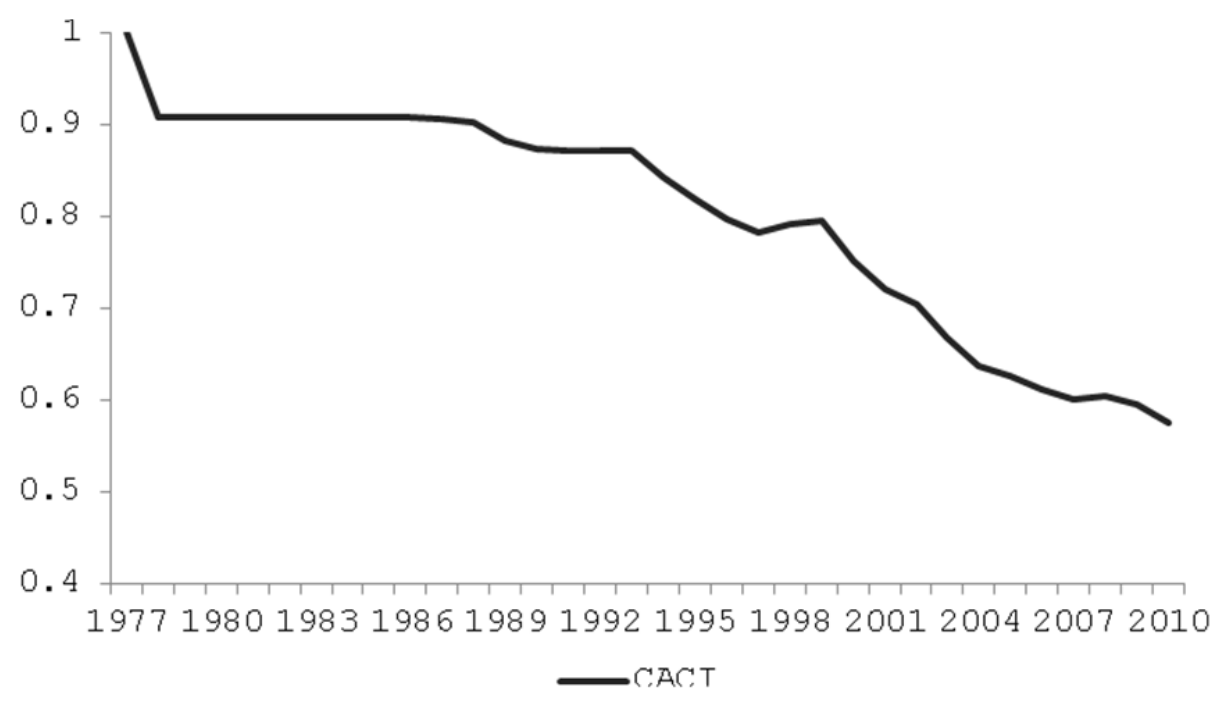

Source: State Administration of Foreign Exchanges of China (SAFE) and authors' calculations. 
Figure 2 Financial Openness Index for China, 1981-2010

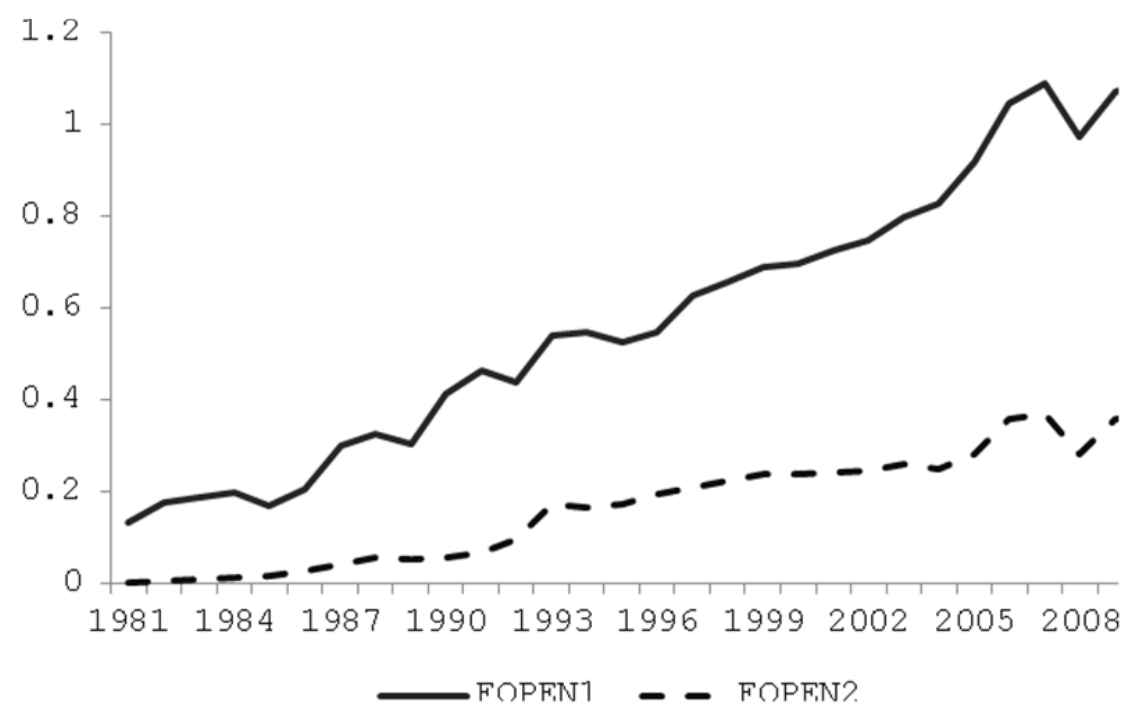

Source: Lane and Milesi-Ferretti (2007), International Investment Position from SAFE and authors' calculations. 
Figure 3 The Ratio of FDI to GDP at the Provincial Level: 2001-2010

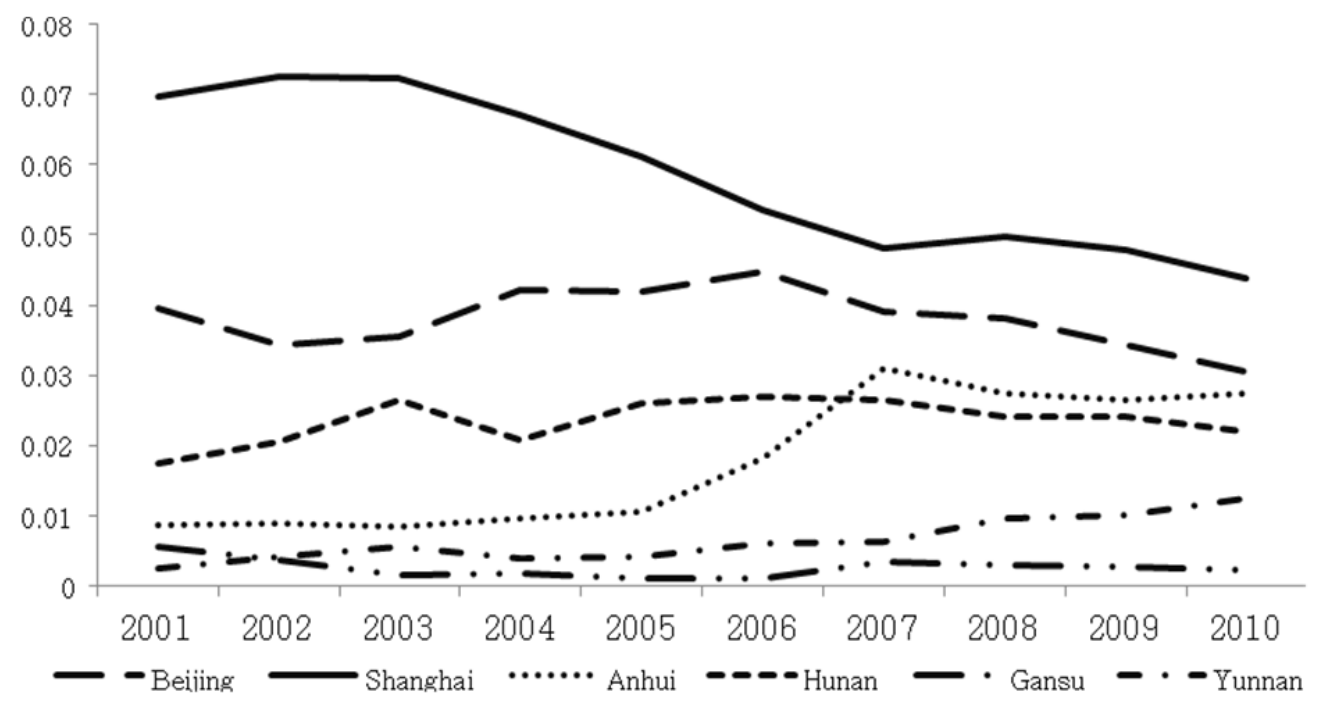

Source: NBS, Statistical Bulletin of China's Outward Foreign Direct Investment, and author's calculations. 
Figure 4 the Ratio of OFDI at the Provincial Level: 2003-2010

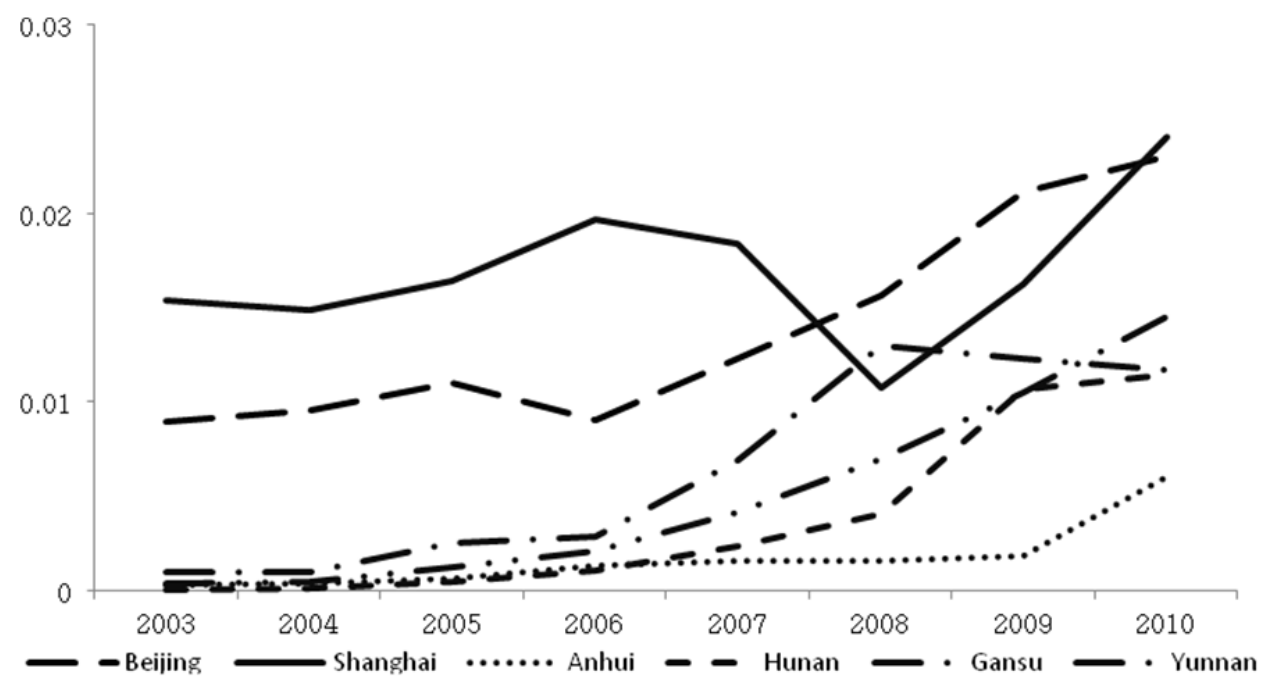

Source: NBS, Statistical Bulletin of China's Outward Foreign Direct Investment, and author's calculations. 
Figure 5 Financial Openness Index at the Provincial Level: 2001-2010

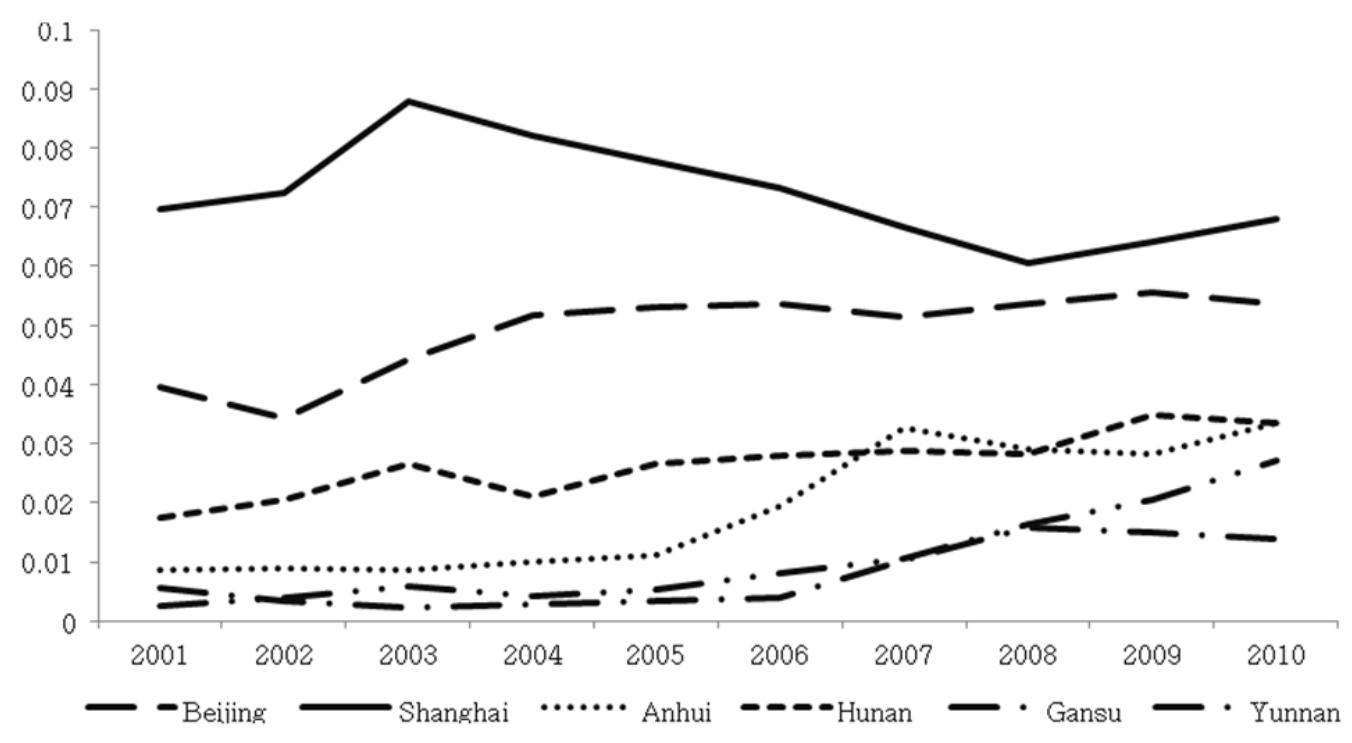

Source: NBS, Statistical Bulletin of China's Outward Foreign Direct Investment, and author's calculations. 